\title{
RESEARCH AT KU: MOVING AHEAD!
}

\author{
Robert E. Barnhill \\ Vice Chancellor for Research and Public Service \\ President, KU Center for Research \\ University of Kansas
}

I am pleased to respond to Dr. Martin Apple's opening remarks at this sixth annual research policy meeting sponsored by the Merrill Advanced Studies Center. This is my fifth opportunity to speak at these important meetings. I wish to emphasize our gratitude to Fred and Virginia Merrill for their continuing support of these sessions.

I want to talk about our university's response to the post 9-11 American situation, but first, I will review a few macro-level statistics about the research enterprise at the University of Kansas (KU) in order to set the framework from which 9-11 responses can occur.

The first portion of my talk involves research performance measures - a theme at last year's Merrill Conference. You will recall that Joan Lorden from the University of Alabama - Birmingham discussed them in some detail. I'll mention three kinds of performance measures:

$>$ Research, development and training expenditures (RDT)
$>$ Research rankings
$>$ Research market share

Then I will touch briefly on post $9-11$ by means of quotations from John Marburger and Rita Colwell. I'll conclude with a report on a recent KU-Midwest Research Institute bio-defense workshop that we initiated and co-organized.

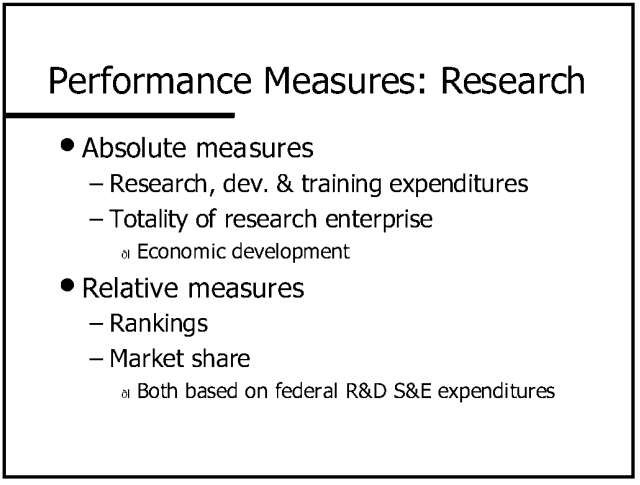

Academic research is multidimensional and thus requires a variety of measures. These measures are of two types, either absolute or relative. At KU, we use one principal absolute measure, namely, research, development and training expenditures. This measure involves the totality of the research enterprise. Economic development numbers, such as the number of jobs provided in a ripple effect, stem from this RDT number. 
We use two principal relative measures: rankings and market share. Both are based on federal research and development (R\&D) expenditures in science and engineering. These expenditure numbers, collected by the National Science Foundation (NSF), are the "gold standard" for rankings because they represent peer-reviewed research.

For fiscal year 2001, our RDT expenditure figure is $\$ 224$ million. The methodology used to obtain this number is the same as the NSF methodology used for rankings, but it is also applied to non-science and engineering and to training projects.

Our RDT expenditure can be used to estimate economic impacts such as the number of jobs produced by the ripple effect of KU research. The U.S. Department of

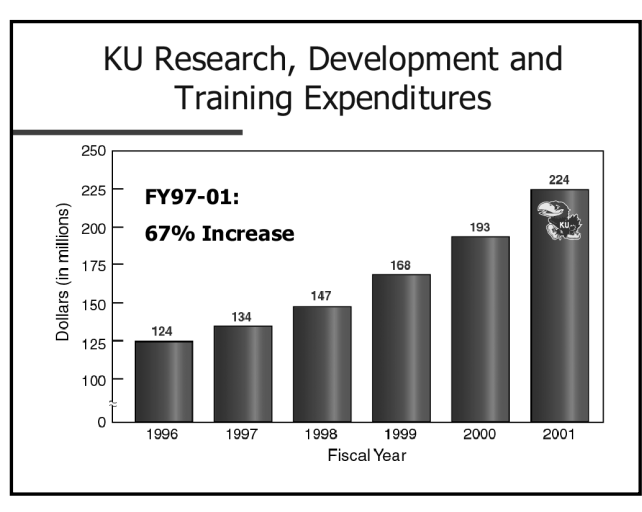
Commerce says that, in Kansas, $\$ 1$ million of academic R\&D produces over 42 jobs; hence $\$ 224$ million produces almost 9,500 jobs.

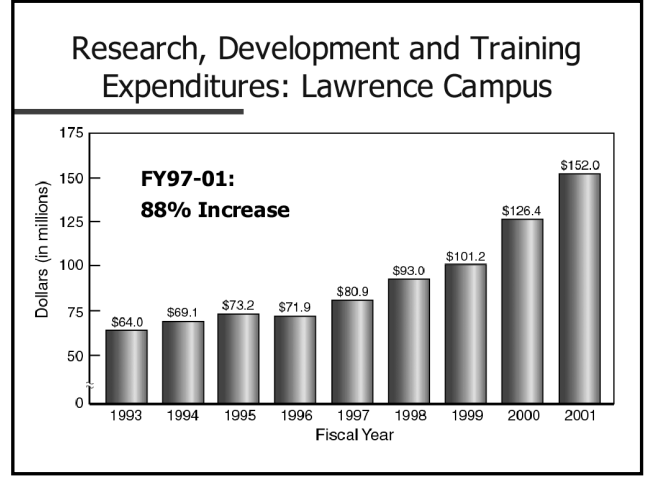

The first relative measure is our ranking based on federal research and development expenditures in science and engineering. Based on this national "gold standard," KU has risen rapidly since KUCR's inception on July 1, 1997.

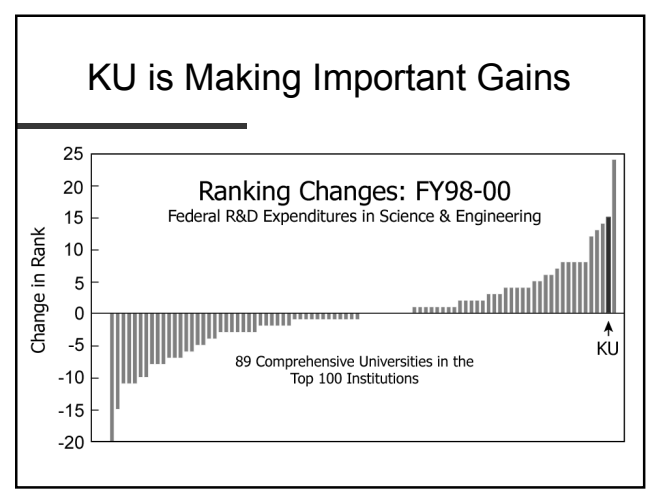

KU's RDT number has increased by 2/3 in the four years from FY 1997-2001 - a significant increase. The RDT expenditure numbers for the Lawrence campus have almost doubled over the four-year lifespan of the KU Center for Research (KUCR) from $\$ 81$ million to $\$ 152$ million. This is a spectacular increase.

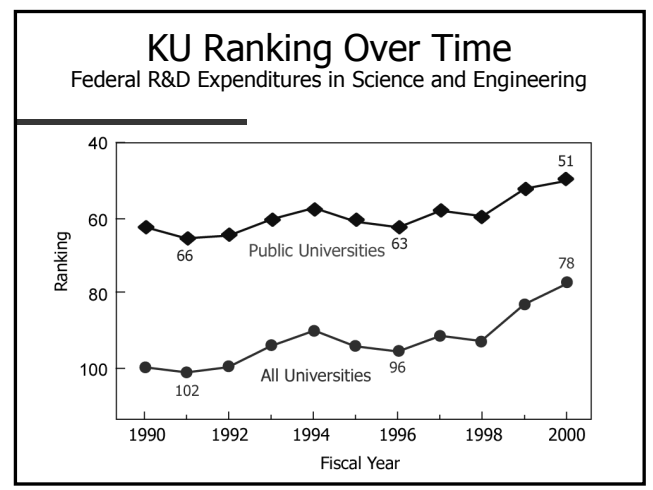

KU's rise in the rankings has taken place very recently. Over the last two fiscal years for which rankings are available - FY 1998 to 2000 - KU jumped in the rankings 15 positions from 93rd to 78th. This jump is the second largest among comprehensive universities in the top 100 . 
A university could be improving in the quality of its research, but not move up in dollars because of federal funding changes or state problems. Another reason for not moving up in the rankings is that the mountain becomes steeper nearer the top. Thus, another useful measure of research progress can be "market share."

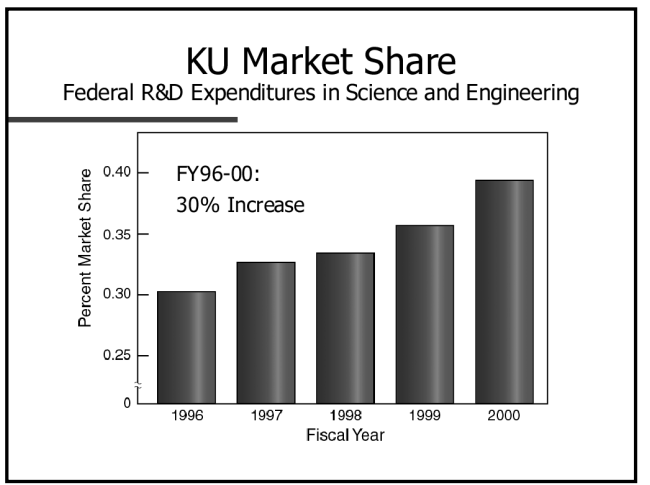

Market share refers to the proportion of federal expenditures spent by an institution. By this relative measure, $\mathrm{KU}$ has increased by $30 \%$ during the five years from fiscal year 1996 through 2000. Note that, by definition, the average change in market share for a given university is zero. Thus, a $30 \%$ increase is significant.

In fact, the market share increase by the KU Lawrence campus has exceeded the increase in market share of all 100 top universities!

Institution

$\mathrm{KU}$ - Lawrence campus

$\mathrm{U}$ of Illinois - Chicago

$\mathrm{U}$ of Colorado

$\mathrm{U}$ of Missouri - Columbia

$\mathrm{KU}$

Washington $U$
\% increase

43.8

36.7

33.8

32.9

30.3

29.5

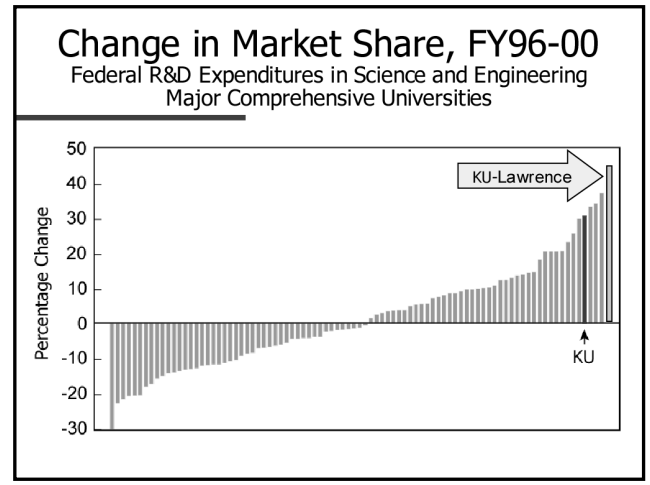

Life Science Research at KU FY 2001

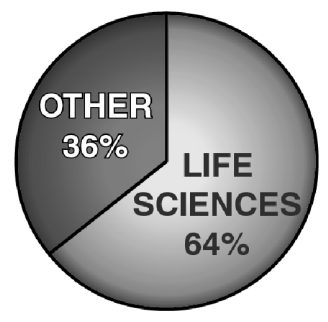

Life sciences is the national research topic most in favor today. For example, the National Institutes of Health (NIH) budget has doubled over the past five years and is now five times the NSF budget. KU's life science research funding is a significant part of our portfolio, representing $64 \%$ of the total. 


\begin{tabular}{|c|c|c|}
\hline \multicolumn{3}{|c|}{$\begin{array}{l}\text { KU Life Sciences } \\
\text { Research Rankings FY99 vs. FY00 }\end{array}$} \\
\hline & $F Y-1999$ & $F Y-2000$ \\
\hline Federal expenditures & $\$ 39$ million & $\$ 47$ million \\
\hline $\begin{array}{l}\text { Ranking among public } \\
\text { universities }\end{array}$ & $44^{\text {th }}$ & $43^{\text {rd }}$ \\
\hline Rank among all universities & $74^{\text {th }}$ & $71^{\text {st }}$ \\
\hline $\begin{array}{l}\text { Places gained among all } \\
\text { universities }\end{array}$ & $\begin{array}{c}10 \text { places } \\
\text { (FY95-99) }\end{array}$ & $\begin{array}{c}15 \text { places } \\
\text { (FY97-00) }\end{array}$ \\
\hline $\begin{array}{l}\text { Public universities with larger } \\
\text { ranking increase }\end{array}$ & 6 & 1 \\
\hline
\end{tabular}

During the four years, fiscal years 1997 to $2000, \mathrm{KU}$ rose 15 positions in federal expenditures in the life sciences, which was the second largest jump in the nation. (The University of South Florida jumped 25 places.)

Our improvement in life science funding has paralleled our improvement in overall research funding.
$\mathrm{KU}$ ranked $35^{\text {th }}$ among comprehensive public universities in federally sponsored life sciences research expenditures in FY 2000. KU's rate of increase in federally sponsored life sciences research expenditures from fiscal years 1996 - 2000 was the highest in the country among the nation's top 50 comprehensive public universities.

\begin{tabular}{|c|c|c|c|c|c|c|}
\hline \multicolumn{7}{|c|}{$\begin{array}{l}\text { Federal Research Expenditures } \\
\text { KU Life Sciences }\end{array}$} \\
\hline Fiscal & \multicolumn{2}{|c|}{ All Institutions } & \multicolumn{2}{|c|}{ KU Total } & \multicolumn{2}{|c|}{ Lawrence Campus } \\
\hline Year & Amount & $\%$ Change & Amount & $\%$ Change & Amount & $\%$ Change \\
\hline 1996 & $7,388,936$ & --- & 25,069 & +-- & 5,265 & --- \\
\hline 1997 & $7,761,199$ & 5.0 & 28,565 & 13.9 & 7,130 & 35.4 \\
\hline 1998 & $8,330,474$ & 7.3 & 28,377 & -0.7 & 8,062 & 13.1 \\
\hline 1999 & $8,942,577$ & 7.3 & 38,866 & 37.0 & 14,770 & 83.2 \\
\hline 2000 & $10,059,880$ & 12.5 & 46,879 & 20.6 & 18,044 & 22.2 \\
\hline 2001 & --- & --- & 54,887 & 17.1 & 24,441 & 25.3 \\
\hline 1996-00 & & 36.1 & & 87.0 & & 242.7 \\
\hline \multicolumn{7}{|c|}{$\begin{array}{l}\text { Source: National Science Foundation and KU Center for Research } \\
\text { KU ranked 35th in federally sponsored life science research expenditures } \\
\text { among comprehensive public universities in FY2000. }\end{array}$} \\
\hline \multicolumn{7}{|c|}{$\begin{array}{l}\text { - KU was number one in federal life science research growth rate among the } \\
\text { nation's top } 50 \text { comprehensive public universities from FY } 1996 \text { to FY } 2000 .\end{array}$} \\
\hline
\end{tabular}

Science at a Time of National Emergency

- Historical perspective

- Vannevar Bush during WWII

"Science has a simple faith, which transcends utility...It is the faith that it is the privilege of man to learn to understand, and that this is his mission. If we abandon that mission under stress we shall abandon it forever, for stress will not cease. Knowledge for the sake of understanding, not merely to prevail, that is the essence of our being."
The theme of this Merrill Center conference is "Science at a Time of National Emergency." Humans tend to think that all things begin with them, without history. Here are Vannevar Bush's words spoken in 1943 at the height of fighting in World War II (called to my attention by our University of Missouri colleague, Rob Hall, Interim Vice Provost for Research):

"Science has a simple faith, which transcends utility...It is the faith that it is the privilege of man to learn to understand, and that this is his mission. If we abandon that mission under stress we shall abandon it forever, for stress will not cease. Knowledge for the sake of understanding, not merely to prevail, that is the essence of our being."

On November 7, 2001, NSF Director Rita Colwell spoke at the Woodrow Wilson International Center for Scholars in Washington, D.C. Several quotes from her speech follow. The first one emphasizes the need for all of us to join in on this post 9-11 agenda and the need to remember history. 
"Science: Before and After September 11"

- Rita Colwell, Director, NSF:

"At this time of uncertainty, the need for all of you is greater than ever before.

Your experience wisdom, research, and measured debate can bring both historical context and analytical order to precipitate public discussion and debate."
Dr. Colwell quoted the late Rep. George Brown (of California) in a speech at the National Academy of Sciences in 1994. "We must have a research system that arches and bends with society's goals." Emphasizing the need for prediction, in the form of an "anticipatory perspective in our research," Colwell went on to say: "The alternative of not being at the forefront of knowledge is the alternative of being left behind."

Colwell also broached the topic of under-represented groups in science and engineering fields. We are all aware of the need to provide supportive environments in order to encourage women and minorities to enter these fields.

Now, extrapolating beyond Colwell's words, here is another thought: universities and businesses are beginning to complain and gear up in order to deal with SEVIS (the Student and Exchange Visitor Information System) and the tracking of international students. This increased security is necessitated by concerns over these students' national loyalty. If loyalty is to become a criteria for admittance to our science and engineering programs, we should pay heed to a sizeable group of minority citizens whose loyalty to this country, on average, is readily apparent.

\begin{tabular}{|l|}
\hline $\begin{array}{c}\text { Rita Colwell Speech } \\
\text { (concluded) }\end{array}$ \\
\hline "...our national need for scientists and \\
engineers cannot possibly be fuffilled by \\
the tradititinal white male population. \\
We must focus on attracting women \\
and our diverse minority populations to \\
these professions." \\
\end{tabular}

The same minorities that are underrepresented in science and engineering fields are vastly over-represented in our country's military branches. An FY99 Department of Defense report on social representation in U.S. military forces reveals that AfricanAmericans provided $20 \%$ of our active duty personnel while they make up only $14 \%$ of the civilian population; the group labeled "Others," including American Indians, were $7 \%$ and $5 \%$, respectively. Hispanics were $11 \%$ and $15 \%$, respectively; hence, Anglos are $62 \%$ and $66 \%$. What more loyal pool of untapped talent could be found than those minorities, those American citizens, who are currently under-represented in our science and engineering programs?

Of course, this is not a "quick fix" answer to the looming question of who will fill the ranks in our science and engineering programs, but it is one that every 


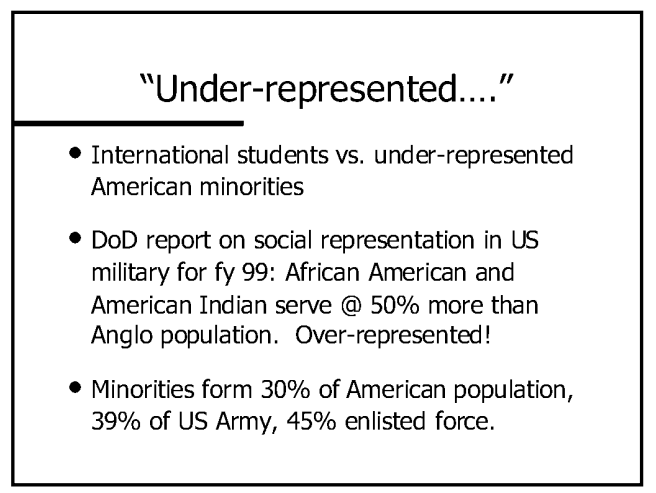

state and local school board can begin addressing immediately. Curriculum experts in our Schools of Education should collaborate with scientists and engineers and with social scientists who understand minority cultures to develop programmatic content and appropriate teaching techniques for kindergarten through $12^{\text {th }}$ grade education. Science and engineering faculty in the academy might also benefit from some teaching tips. If our minority students have a firm foundation in the sciences, they will be more likely to enter undergraduate and graduate programs in science and engineering.

As I often like to say, a rising tide raises all boats. An additional positive point to this idea is that our majority white students will also benefit. Over time, newer educational programs will also encourage their participation in science and engineering programs.

Dr. John Marburger is the Director of the Office of Science and Technology Policy in the Executive Office of the President of the

John Marburger, Director, OSTP CSSP Speech, May 2002

- Historical context

- The Manhattan Project during WWII

- Sputnik in 1957

- Tradition of Manhattan Project $\rightarrow$ university research

- War on terrorism and continuing need for investment in research United States. Last month he gave a speech at a meeting of Martin Apple's Council of Scientific Society Presidents.

\section{Terrorism: Role of Social Sciences}

- CSSP meeting in December 2001, Martin Seligman, President of APA:

" 'Terrorism' is a social phenomenon."

- AAAS Colloquium on S\&T Policy, April, 2002, John Marburger, Director of OSTP: social science provides "structure and dimension to the (post 9/11) discussion" and should be systematically included.
Like Rita Colwell, Marburger began with a historical perspective on American federal science funding and progress. He said, "the modern era of federal science policy begins with World War II and the remarkable contributions the sciences made to the war effort." He went on to cite Sputnik in 1957 as a second epochal event.

Marburger spoke about our current war on terrorism, noting that much of the needed science already exists and remains to be suitably implemented. He went on to say that this does not mean we should slow the investment in science: "The reason we have the needed technology at hand is that the forces of economic competitiveness and the desire to improve the quality of life for all people has driven science and technology in the right direction to address terrorism issues."

Given the Merrill Center's position in KU's Life Span Institute, which focuses on the social sciences, I raise the very illuminating comment from Martin 
Seligman, President of the American Psychological Association. At the December 2001 CSSP meeting, Marty Seligman pointed out that the goal of "terrorism" is to cause social upheaval. Terrorism per se does not seek mass physical destruction except as a means towards this end. As with all great insights, this is obvious after it is pointed out to you.

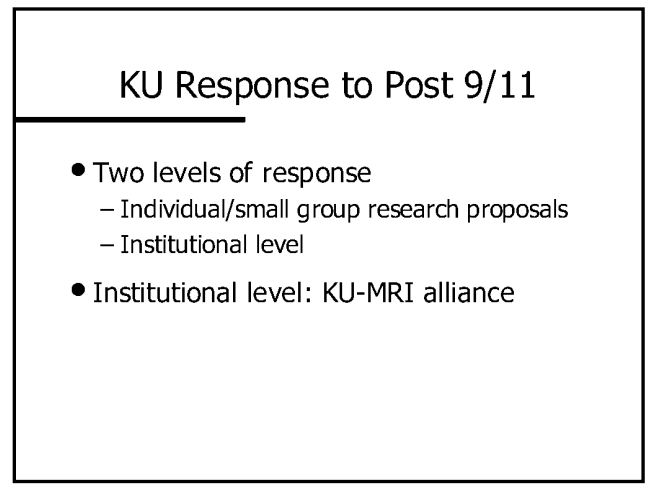

University faculty, the same as other American citizens, wish to contribute to the antiterrorism effort.

$\mathrm{KU}$ research is now sufficiently robust that there is much to contribute. There have been many individual and group research proposals to this end. At the institutional level, we decided to work with the Midwest Research Institute within our KU-MRI Alliance for two reasons: MRl's own expertise in science and their expertise in dealing with a broad range of federal projects.

We sponsored a "bio-defense" workshop under the KU-MRI alliance. The 40 invited participants spent a day discussing our "in-house" areas of expertise and their possible matches to national interests. The principal topics that emerged were vaccines, biosensors and public health. This is a continuing effort and a second workshop will be held this fall.

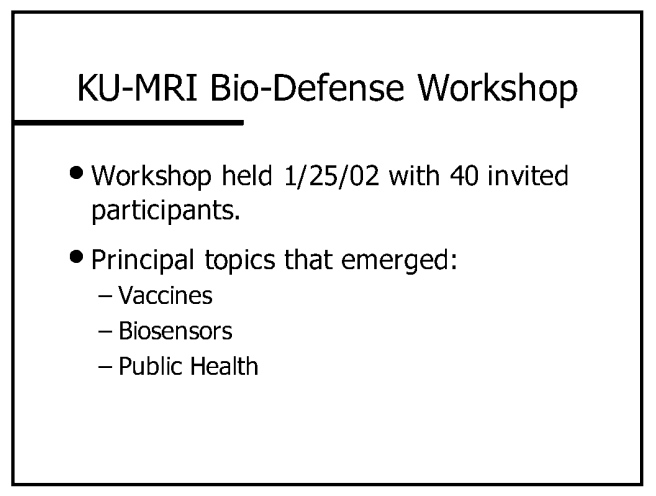

I conclude with two quotations from our own Senator Pat Roberts. The first is from his invited address at last fall's annual meeting of NASULGC, the National Association of State Universities and Land Grant Colleges.

The Senator spoke about post 9-11 and university research, finishing up with this statement:

"A renewed commitment today to our institutions of higher education and especially to science, engineering and technology research is a commitment to our nation's future." 
Senator Roberts was invited to address the AAAS, the American Association for the Advancement of Science, at its Science and Technology Policy Colloquium in April, 2002. Let me conclude my remarks by quoting the Senator's words on that gala occasion:

"I believe strongly in the need for engineering, science and technology research as a tool to improve the quality of life for all Americans. And after September $11^{\text {th }}$, this research is not only vital for thriving in an economically competitive world, it must be vigorously pursued. We will respond like the United States has to previous global events such as the Cold War and Sputnik."
Senator Pat Roberts - KS AAAS S\&T Policy 4/02

- "I believe strongly in the need for engineering, science and technology research as a tool to improve the quality of life for all Americans. And after September $11^{\text {th }}$, this research is not only vital for thriving in an vigorously pursued. We will respond like the United States has to previous global events such as the Cold War and Sputnik." economically competitive world, it must be 